\title{
Analysis of Heat Pressure with Systolic-Diastolic Blood Pressure and Fatigue in Karak Industrial Workers Gadingan Sukoharjo
}

\author{
Seviana Rinawati ${ }^{1, *}$, Siti Utari $^{1}$, Siti Rachmawati $^{1,}$, and Iwan Suryadi ${ }^{1}$ \\ ${ }^{1}$ Program of Occupational Health and Safety, Faculty of Medicine, Sebelas Maret University, Surakarta - Indonesia
}

\begin{abstract}
The Karak industry is a food processing industry that has the potential danger of heat stress. Heat pressure can cause workers to experience health problems, especially if peripheral blood vessel dilatation causes circulatory disorders and can also cause fatigue. The aim of this study to analyze the heat pressure with blood pressure and fatigue in Karak industrial worker. This type of research is observational analytic, cross-sectional design with purposive sampling consist of 106 respondents. Test statistical data of research with Spearman Correlation. The Karak industry workplace has a WetBulb Globe Temperature (WBGT) $34^{\circ} \mathrm{C}$ in 8 hours/day with mild workloads. The significance of the relationship between heat pressure and systolic-diastolic blood pressure about $\mathrm{p}=0.034$ and $\mathrm{p}=0.031$; the value of $\mathrm{r}=-0,338$ and $\mathrm{r}=$ $-0,358$ which means the strength of the correlation is weak. And the significance of heat pressure with fatigue is $p$-value $=0.039$ and $r=-0.581$ (the strength of the medium correlation). There was a correlation between heat pressure and systolic-diastolic blood pressure and fatigue in Karak industrial workers Gadingan Sukoharjo.
\end{abstract}

Keywords: heat pressure; blood pressure; fatigue.

\section{Introduction}

Workers are active in the workplace with physical environmental conditions that can affect health and safety disturbances. The danger of overheating workplace conditions, lack of lighting, excessive vibration and other physical conditions can lead to health problems for workers [1].

The heat stress in the workplace can be caused due to the presence of heat sources or due to poor ventilation [2]. Excessive heat conditions will result in fatigue and drowsiness, reduce stability and increase the number of workplace errors [3]. Whereas according to [4] the heat temperature makes it less agile, long reaction time and slow in decision making, coordination of taste and motor nerves is disturbed and eases emotions to be stimulated. The heat stress can also cause the dilation of peripheral blood vessels so that the circulatory balance is disrupted. Excessive sweating, reducing plasma volume so that blood volume also decreases as a result of decreased systolic-diastolic and lack of oxygen supply to the brain then people will lose consciousness [5]. Environmental temperature measurements are carried out by measuring components temperature consisting of dry temperature, natural wet temperature, and radiant temperature. It is also necessary to measure relative humidity and wind speed. General Environmental Temperature was announced with the Wet Bulb Globe Temperature index (WBGT) which aims to find out workers who are at risk of heat stress.

The preliminary survey obtained WBGT data of $35.8^{\circ} \mathrm{C}$ (calculation of pulse rate between $87-100$ so that it included light workload categories) and blood measurement results for 17 workers experienced an increase in systolic and diastolic blood pressure by 10 workers. The fatigue questionnaire showed that $67 \%$ of workers from 27 workers experienced symptoms of fatigue, thirst, feeling dizzy when standing after squatting for too long, disturbed concentration in work. If exposure to heat stress continues, there will be an increase in health problems, so prevention or control needs to be done. The researchers are interested in the Analysis of Heat Pressure with Systolic-Diastolic Blood Pressure and Fatigue in Karak Industrial Workers Gadingan Sukoharjo. The aim of this research to an analysis of heat pressure with systolic-diastolic blood pressure and fatigue in Karak industrial workers.

\section{Research Methods}

This type of research is analytic observational with a cross-sectional approach because the research variables are measured at the same time and carried out in the same situation [6]. The Karak industry in Gadingan Sukoharjo is a home industry in one study area so that samples were taken by purposive sampling with criteria: age $18-50$ years, men, willing to be respondents obtained by 104 people from 23 home-based Karak industries in the region in January 2019. Instruments for measuring heat pressure are heat stress Area Monitor, a Sphygmomanometer is used to measure systolic and diastolic blood pressure and reaction timers used to measure fatigue. Analysis of research data using

Corresponding author: sev1ana_er@staff.uns.ac.id 
bivariate analysis of heat pressure with systolic-diastolic and heat pressure with fatigue using Spearman correlation [7].

\section{Result}

This charcoal industry processes raw materials in the form of rice to be produced into raw and fried charcoal. Respondents numbered 104 males aged 21-49 years (mostly at the age of 38-45 years). The highest activity is exposed to heat in the production process, namely frying. Workers' activities when using charcoal stoves using heating stoves around $100^{\circ} \mathrm{C}$ with hot cooking oil between $80-90{ }^{0} \mathrm{C}$. the results of heat stress measurements used a heat area stress monitor are obtained in Table 1.

Table 1. Results of the heat pressure measurement in Karak industry

\begin{tabular}{|c|c|c|c|c|c|}
\hline $\begin{array}{c}\text { Measurement } \\
\text { (WBGT) }\end{array}$ & $\begin{array}{c}\text { Mean } \\
\left({ }^{0} \mathbf{C}\right)\end{array}$ & $\begin{array}{c}\text { Min } \\
\left({ }^{\circ} \mathbf{C}\right)\end{array}$ & $\begin{array}{c}\text { Max } \\
\left({ }^{\circ} \mathbf{C}\right)\end{array}$ & $\begin{array}{c}\text { Range } \\
\left({ }^{\circ} \mathbf{C}\right)\end{array}$ & $\begin{array}{c}\text { STD } \\
\left({ }^{\circ} \mathbf{C}\right)\end{array}$ \\
\hline Heat pressure & 34.162 & 30.7 & 35.8 & 2.8 & 0.896 \\
\hline
\end{tabular}

The measurement results of the heat pressure exceed the allowable Threshold Value (TLV) that it has not according to the Republic of Indonesia Minister of Manpower Regulation Number 5 the Year 2018 concerning Occupational Safety and Health with a mild workload of $31.0^{\circ} \mathrm{C}$ for 8 hours/day. So that following with article 9 (4) If the results of the workplace measurement as referred to in paragraph (2) and paragraph (3) exceed the TLV or the standard must be controlled. The owner of the Karak industry has not taken control but has provided drinking water as an effort to impact the exposure to heat stress [8].

Systolic measurements a higher than diastolic in the Gadingan Sukoharjo Karak industry. The measurement results with the sphygmomanometer can be shown in the following Table 2 .

Table 2. Results of systolic-diastolic workers measurement in the Karak industry

\begin{tabular}{|c|c|c|c|c|c|}
\hline $\begin{array}{c}\text { Blood } \\
\text { pressure } \\
\text { (mm Hg) }\end{array}$ & Mean & Min & Max & Range & STD \\
\hline Systolic & 143.74 & 123 & 186 & 65 & 13.912 \\
\hline Diastolic & 91.12 & 81 & 102 & 23 & 6.287 \\
\hline
\end{tabular}

Workers in the industries of Karak in this study male sex respondents all are in according to opinion [9] which stated generally male blood pressure is higher than women. Women have a risk of hypertension and will increase after the menopause that shows the influence of hormones.

Research Data conducted with measurements using the reaction timer shows workers experiencing fatigue at the highest level is 798.7 milliseconds and the lowest at
230 milliseconds. The measurement results can be shown in Table 3.

Table 3. Result of fatigue measurement in Karak Industrial workers

\begin{tabular}{|c|c|c|c|c|c|}
\hline $\begin{array}{c}\text { Measurement } \\
\text { (milliseconds) }\end{array}$ & Mean & Min & Max & Range & STD \\
\hline Fatigue & 393.3 & 230.0 & 798.7 & 568.7 & 144.7 \\
\hline
\end{tabular}

Worker fatigue is greater on the fatigue of mild and slight levels in the weight category. The result is according to [10] that the working environment, in addition to heat exposure is noisy that will affect the body's faal such as autonomic nerve disorders that characterized increased metabolism and muscle tension that speeds up the fatigue.

The results of a statistical test of heat pressure with systolic-diastolic blood pressure, test statistics on heat pressure with fatigue, a statistical test of systolicdiastolic relations with fatigue and statistical test of age relationship with heat pressure, systolic-diastolic and fatigue can be seen in Table 4 below.

Table 4. Results of Spearman correlation in research variables

\begin{tabular}{|c|c|c|c|c|c|}
\hline $\begin{array}{c}\text { Spear- } \\
\text { man Test }\end{array}$ & $\begin{array}{c}\text { Corelation } \\
\text { / Value }\end{array}$ & \multicolumn{2}{|c|}{$\begin{array}{c}\text { Systolic blood } \\
\text { pressure }\end{array}$} & \multicolumn{2}{|c|}{$\begin{array}{l}\text { Diastolic blood } \\
\text { pressure }\end{array}$} \\
\hline \multirow{3}{*}{$\begin{array}{c}\text { Heat } \\
\text { pressure }\end{array}$} & $\mathrm{r}$ & \multicolumn{2}{|c|}{-0.338} & \multicolumn{2}{|c|}{-0.358} \\
\hline & $\mathrm{p}$ & \multicolumn{2}{|c|}{0.034} & \multicolumn{2}{|c|}{0.031} \\
\hline & \multicolumn{3}{|c|}{ Corelation / Value } & \multicolumn{2}{|c|}{ Fatigue } \\
\hline \multirow{3}{*}{$\begin{array}{c}\text { Heat } \\
\text { pressure }\end{array}$} & \multicolumn{3}{|c|}{$r$} & \multicolumn{2}{|c|}{-0.581} \\
\hline & \multicolumn{3}{|c|}{$\mathrm{p}$} & \multicolumn{2}{|c|}{0.039} \\
\hline & $\begin{array}{c}\text { Corelation } \\
\text { / Value }\end{array}$ & \multicolumn{2}{|c|}{$\begin{array}{c}\text { Systolic blood } \\
\text { pressure }\end{array}$} & \multicolumn{2}{|c|}{$\begin{array}{l}\text { Diastolic blood } \\
\text { pressure }\end{array}$} \\
\hline \multirow{3}{*}{ Fatigue } & $\mathrm{r}$ & \multirow{2}{*}{\multicolumn{2}{|c|}{$\begin{array}{l}0.526 \\
0.002\end{array}$}} & \multicolumn{2}{|c|}{0.531} \\
\hline & $\mathrm{p}$ & & & \multicolumn{2}{|c|}{0.002} \\
\hline & $\begin{array}{l}\text { Corela tion } \\
\text { / Value }\end{array}$ & $\begin{array}{c}\text { Heat } \\
\text { pressure }\end{array}$ & $\begin{array}{c}\text { Systolic } \\
\text { blood } \\
\text { pressure }\end{array}$ & $\begin{array}{c}\text { Diastolic } \\
\text { blood } \\
\text { pressure }\end{array}$ & Fatigue \\
\hline \multirow{2}{*}{ Age } & $\mathrm{r}$ & 0.016 & 0.630 & 0.520 & 0.309 \\
\hline & $p$ & 0.923 & 0.000 & 0.001 & 0.085 \\
\hline
\end{tabular}

\section{Discussion}

Based on Table 4 it can be noted that there is a relationship between heat pressure and systolic-diastolic blood pressure in Karak Gadingan industrial workers Sukoharjo shown from the significance between two variables with $\mathrm{p}=0.034$ and $\mathrm{p}=0.031(\mathrm{p}$-value $<0.05)$ means correlation between two variables tested, for the strength of the correlation with the value $r=-0.358$ and $r$ $=-0.388$ means the strength of the correlation is weak. The direction of correlation - (negative) has a meaning that is if the heat pressure is high then the systolicdiastolic blood pressure is low and if the heat pressure is low then the systolic-diastolic blood pressure is high. 
The heat stress can cause muscle spasms due to loss of fluid and salt due to excessive sweating and impact the tendency of the heart circulation less adequate (blood pressure decreases) and The pulse is faster than normal conditions. That corresponds to the statement [11] that And strengthened by [11] posited: The heat stress can cause heat strain (hot strain) that raises pulse rate, body temperature, blood pressure, sweat expenditure, and weight loss. As well as the study of [12] about the difference in blood pressure on hot-exposed workers in the industry of banana love Ciamis $\left(32.5^{\circ} \mathrm{C}\right)$ with the provision of white water consumption have a positive impact on the blood pressure of workers so as to improve the decrease in blood pressure due to the exposure to heat stress .

Working conditions that have not been accompanied by a good ventilation system become one of the causes of the heat stress to become redundant, the workplace is enclosed because if there is large ventilation can affect the heater when frying.

Based on tests Spearman is known to have a heat stress relationship with fatigue on the workers shown from the value $p=0.039(p<0.05)$ which means there is a meaningful correlation between the two tested variables, while for the strength of the correlation is $r=$ 0.581 and the direction of correlation - (negative) with moderate correlation strength, i.e. if the heat pressure is high then fatigue is low and if the heat stress is low then fatigue is high.

According to [1] Physiological reactions due to heat exposure over the TLV cause physiological reactions ranging from the simplest physiological disorder to very severe diseases. [13] on heat stress with fatigue on the labor field of Furniture $(\mathrm{p}=<0.001)$ indicates there is a relationship between heat stress with fatigue on the labor production part at PT Rakabu Furniture Surakarta. The same thing with [14] Research on heat stress with employee fatigue room with results $p=0.026$ indicates there is a relationship between heat pressure with fatigue complaints.

The results of this research also strengthened by [2] statement that fatigue is an early symptom of various types of health disorders due to heat pressure.

Statistical test result of systolic-diastolic blood pressure relationship with the fatigue in industrial worker Karak Gadingan Sukoharjo shown from the significance value between the two variables, that is the same $p$-value of $p=0.002(p<0.05)$ i.e. there is a meaningful correlation between two variables and the power of the correlates is $r=0.526$ and $r=0.531$ and for the direction of correlation + (positive) with strong correlation strength, that is if the systolic-diastolic blood pressure High then the fatigue is high and if the systolicdiastolic blood pressure is low then the fatigue is low

This research Data in accordance with the theory of [4] suggests that if there is a decrease in blood flow then lactic acid will accumulate thereby causing fatigue.

The correlation test between the ages and the heat stress is insignificant i.e. the value $p=0.923(p>0.05)$ means there is no meaningful correlation between age and the heat stress.
Data of respondents in the Karak industry has a range of ages 21-49 years, hence the known reference that the age of the respondent is still under normal limitation for the increase and decrease in systolic and diastolic. This is in agreement with [15] That blood pressure will tend to increase simultaneously with age. In general, systolic increases in line with the increase in age, and diastolic will increase to the age of 55 years, then decreases back.

Furthermore, the correlation between age with significant systolic-diastolic blood pressure with the value $p=<0.001$ and $p=0.001(p<0.05)$ which means there is a meaningful correlation between the age with systolic-diastolic blood pressure with the correlation power of $r=0.630$ and $r=0.520$ and the direction of the correlation + (positive) with a strong correlation force that is if the age increases then systolic-diastolic blood pressure will increase.

The correlation agrees with [16] regarding the correlation of nutritional status, gender, age, blood group and descent history with blood pressure civil servants in Pekanbaru with the results there is a correlation between the age with systolic blood pressure and Diastolic value $\mathrm{P}=<0.001$ and $\mathrm{p}$-value $=0.003$. The same research by [17] Supporting the characteristics of workers with the blood pressure of female workers in the Yogyakarta textile company with statistical test results on systolicdiastolic blood pressure with the age of p-value 0.002 and p-value 0.008 .

The relationship between age and fatigue is not significant with the value $p=0.085(p>0.05)$ means there is no meaningful correlation between age with fatigue.

The research is in line with [18], mentions that there is no relationship between the age with the fatigue of an IGD nurse at RSUD Haji Makassar.

Based on the characteristics of all male sex respondents, [19] suggests that males have more muscular work strength than women, but based on respondents' age characteristics, all respondents Aged over 40 years old. This is in accordance with the research conducted by [20], it is noted that at the age above 40 years tend to suffer from fatigue followed by decreased organ capability, causing workers to become more easily experienced Fatigue. Seeing this, we recommend that companies impose adequate rest and provide drinking water to the workers.

The final results show that heat pressure is more related to blood pressure than fatigue. Heat pressure with diastolic blood pressure $(\mathrm{p}=0.031)$ and weak correlation ( $\mathrm{r}=-0.358)$.

The new evolution of the production and industrial process called Industry 4.0, and its related technologies such as the Internet of Things, big data analytics, and cyber-physical systems, among others, still have an unknown potential impact on sustainability and the environment to welcome industry 4.0, the connection between the solution to reduce heat pressure on workers can be done by making smart jackets using the microsensor controller methods in accordance with a research by Devi and Kumar about the use of arm on jackets to adjust to climate change [21] 


\section{Conclusion}

There is a relationship between heat pressure with systolic-diastolic blood pressure and fatigue in Karak industrial worker Gadingan Sukoharjo.

\section{References}

1. Maurits, L. Setyawati, Fatigue Overview. Amara Book (2010)

2. Subaris, Haryono, Environmental Hygiene work, Mitra Cendikia Press (2008)

3. E. Nurmianto, Ergonomics of basic concepts and applications, Guna Wijaya (2008)

4. Suma'mur, Corporate Hygiene and Occupational Health (HIPERKES), CV Sagung Seto (2014)

5. H.N.C. Stam, Occupational Safety and Health in Place, Intergrafika (1989)

6. S. Notoatmodjo, Health research Methodology, Rineka Cipta (2010)

7. Sugiyono, Statistics for Research, Alphabet (2011)

8. Regulation of the Minister of Manpower RI Number 5 on occupational safety and health work environment (2018)

9. Purwanto, Hypertension (pathogenesis, breakdown of Target organs, and management), UNS Press (2012)

10. H. Setiarto, Thesis (2002)

11. S. Wignjosoebroto, Thesis (2003).

12. S. Ari, D. Lestantyo, Yulisnawati, IPI-cite 56 (2008)

13. R.D. Krisanti, Thesis (2011)

14. Y.A. Iqbal, M.F. Naiem, M.R. Rahim, Climate relations work with employees' fatigue laundry parts in Makassar City, IPI-cite 1 (2014)

15. Vitahealth, PT Gramedia Pustaka Utama (2006)

16. H. Harahap, Hardinsyah, B. Setiawan, I. Effendi, IPI-Cite 2, 51-58. 9 (2008)

17. Muchsin, Haryono, Rosyidah, IPI-Cite 4, 1-5 (2008)

18. M. Fatmawaty, S. Alam, A. Agustina Suyuti, PHS J VIII (2016)

19. Suma'mur, Sagung Seto (2009)

20. J. Atiqoh, I. Wahyuni., D. Lestyanto, PH J 2, 1-5 (2014)

21. S. Annapurna Devi, P.R. Kumar, IJET 2, 125-129 (2016) 